\section{FORMULATION AND EVALUATION OF THE NANOSILVER GEL USING BIOREDUCTOR ETHANOL EXTRACT OF KATUK LEAF (SAUROPUS ANDROGYNUS (L) MERR) AS ANTIBACTERIAL}

\author{
Nurfadilah $^{1 *}$, Yunahara Farida ${ }^{2}$ Faizatun $^{3}$ \\ 1,2,3 Faculty of Pharmacy, Universitas Pancasila, \\ Indonesia \\ fadilahh.apoteker28@gmail.com
}

\section{Introduction}

Acne (acne vulgaris) is a chronic inflammatory disease of the pilosebaceus unit, which is characterized by blackheads, papules, pustules, nodules, cysts and scars. Acne often occurs on the skin of the face, neck, chest and back. Although acne has no fatal effects, it is quite worrying as it can reduce confidence, especially those who care about appearance (1).

One type of nanoparticle that is currently receiving great attention in pharmaceuticals is nanosilver because it can act as an antimicrobial agent (2). Nanosilvers are synthesized using plant extracts as reducing agents. This method is an environmentally friendly nanoparticle synthesis method because it can minimize the use of hazardous inorganic materials while minimizing waste, making it better known as a bioreductor. In addition, plant species containing these reducing agents are quite common and readily available in Indonesia.

The working principle of plants in the reduction of silver nanoparticles is the ability of compounds in plants that can reduce charged $\mathrm{Ag}\left(\mathrm{Ag}^{+}\right)$to ago nanoparticles (3). It is known that Ag metal has a positive charge to produce silver metal nanoparticles and then to reduce them to Ago using plant extracts as reducing agents.

Herbal plants that are often found and have many health benefits, namely katuk. Some of the contents of the Katuk plant are bactericides that can kill bacteria, including flavonoids, saponins, sesardic acid, papaverinal alkaloids, tannins, mineral salts, and essential oils. Studies by Mukhriani (2014) also showed that the methanol extract from Katuk leaf (Sauropus androgynus) has an antibacterial effect against Staphylococcus aureus and Salmonella thyposa (4).

In this study the biosynthesis of silver nanoparticles was carried out using katuk leaf ethanol extract. Katuk contains flavonoids in the form of polyphenols, which theoretically have reducing properties. So far, there have been no research reports using these extracts as reducing agents, especially transition metals such as silver. The silver source used in this research is silver nitrate, which is further formulated in the form of an effective gel preparation as an antibacterial agent that causes acne.

\section{Materials and Methods Tools and materials}

The tools used in this study were Transmission Electron Microscope TEM-1400 23 (JEOL Ltd., Japan), PSA(particle analyzer of the Litesizer ${ }^{\text {TM }}$ series), FTIR (P3 NEUTRAPON) 5088), analytical scales with a sensitivity of $0.1 \mathrm{mg}$ (labPRO DT224C), pH meter (OHAUS), oven, viscometer (Lamy viscometer) and other glassware.

The ingredients used in this study were katuk leaf, ethanol 96\% (Brataco Chemical, Indonesia), $\mathrm{AgNO}_{3}$ (Merck), Carbomer 940, propylene glycol, phenoxyethanol, TEA, Aquadest, brain-heart infusion agar (BHIA), brainheart - Infusion Broth (BHIB), Trypton Soy Agar Media (TSA) and Trypton Soy Broth (TSB); Propionibacterium acnes and Staphylococcus aureus bacteria, obtained from the Microbiology Laboratory of the Department of Biology, IPB.

The Katuk leaf used come from the Bogor region. Katuk leaf are dried by indirectly airing them in the sun for 1 week.

The dried Simplisia katuk is made from fine powder and macerated using a $96 \%$ ethanol solvent, stirred and left to stand for 24 hours and then filtered. The filtrate is evaporated with a vacuum rotary evaporator. The resulting liquid extract is then heated on a water bath at $50^{\circ} \mathrm{C}$ while stirring is continued and a thick extract is made from Katuk leaf.

Before $\mathrm{AgNO}_{3}$ powder or silver nitrate is synthesized, silver nitrate is first converted into a liquid form with a concentration of $10 \mathrm{mM}$ with a silver nitrate weighing up to $0.85 \mathrm{~g}$. Then silver nitrate is dissolved in distilled water up to $500 \mathrm{ml}$ at the same time in a beaker and then stirred until it is mixed homogeneously (5).

\section{Green synthetic nanosilver}

In this study, nanosilver synthesis was performed based on previous research(2). Nanosilver synthesis was carried out by adding $10 \mathrm{ml}$ of katuk leaf ethanol extract and then $90 \mathrm{ml}$ of $10 \mathrm{mM}$ silver nitrate solution. Then stir and heat to $40^{\circ} \mathrm{C}$ at a rate of $200 \mathrm{rpm}$ until the brown color changes.

\section{Optimized the minimum inhibitory concentration of Nanosilver Katuk Leaf Ethanol Extract}

The optimization of the minimum inhibitory concentration of the ethanol extract from Nanosilver Katuk leaf was carried out by the liquid dilution method(6). Production of Nanosilver with a concentration of $0.32 \%$ ethanol extract from Katuk leaf with $10 \mathrm{mM}$ silver nitrate (1: 9) as stock solution. 5 sterile vials prepared for the dilution series.

The bacterial inoculum was prepared by adding 0.1 $\mathrm{ml}$ of bacterial tension in $1 \mathrm{ml}$ of BHIB / TSB medium. Each vial was filled with $1 \mathrm{ml}$ of BHIB / TSB medium. Then dilution is carried out with a pipette from vial $1(0.32$ Nanosilver solution) up to $1 \mathrm{ml}$ in vial $2(0.16 \%)$, then 
removed from vial 2 up to $1 \mathrm{ml}$ and then in vial $3(0,08 \%)$ and $1 \mathrm{ml}$ was removed from the third vial and then placed in vial $4(0.04 \%)$. Then the vials were swirled at $200 \mathrm{rpm}$ and then incubated in an incubator at $37^{\circ} \mathrm{C}$ for 24 hours for $S$. aureus and $P$. acnes for 48 hours in an anaerobic tube. Thereafter, the liquid media culture was incubated and grown to a medium so that TSA was firm for $S$. aureus and BHIA for P. acnes. 24 hours for $S$. aureus and 48 hours for P. acnes.

The concentration at which the bacterial colony begins to grow is then observed. The MIC value is expressed as the lowest concentration of ethanol extract from katuk leaf, which can still inhibit the growth of bacteria that cause acne.

\section{Nanosilver characterization}

The size and zeta potential of the katuk leaf ethanol extract were measured using a PSA particle size analyzer using a solution containing silver nanoparticles, which were taken 1-2 drops and dissolved in water and then stirred until homogeneous, from solution and then put into the solution in $\mathrm{a} \pm 1 \mathrm{ml}$ cuvette and place in a chamber for PSA analysis (7).

The determination of functional groups was analyzed with an FTIR spectrometer (P3 NEUTRAPON 5088 ) in order to determine the functional groups contained in the ethanol extract of Katuk leaf so that they can play a role in the synthesis of silver nanoparticles (8).

The Nanosilver morphology was examined using transmission electron microscopy (TEM) using a few Nanosilver drops dripped onto the TEM grid.

\section{Production of Nanosilver gel}

The Nanosilver gel consisted of nanosilver leaf ethanol extract, Carbomer 940, propylene glycol, phenoxyethanol, TEA, Aquadest and Clindamicyn gel as a positive control. Production of nanosilver katuk leaf extract was carried out on 3 formulas according to (Table 1) with different concentrations of nanosilver ethanol extract from Katuk leaf.

Table 1. Nanosilver gel formula (9).

\begin{tabular}{|c|c|c|c|c|c|c|}
\hline \multirow[t]{2}{*}{ Material name } & \multirow[b]{2}{*}{ Uses } & \multicolumn{5}{|c|}{ weight \% } \\
\hline & & Fo & F1 & F2 & F3 & F4 \\
\hline $\begin{array}{l}\text { Nanosilver Katuk leaf } \\
\text { ethanol extract }\end{array}$ & active ingredient & - & 0,16 & 0,32 & 0,48 & - \\
\hline Clindamicyn gel & $\begin{array}{l}\text { active ingredient } \\
\text { (Positive control) }\end{array}$ & - & - & - & - & 1 \\
\hline Carbomer 940 & Gelling Agent & 1 & 1 & 1 & 1 & - \\
\hline Propylene glycol & Humectant & 15 & 15 & 15 & 15 & - \\
\hline Phenoxyetanol & preservative & 0,8 & 0,8 & 0,8 & 0,8 & - \\
\hline TEA & stabilizer $\mathrm{pH}$ & 0,5 & 0,5 & 0,5 & 0,5 & - \\
\hline Aqudest & Solvent & 100 & 100 & 100 & 100 & - \\
\hline
\end{tabular}

Carbomer was developed into a solution of nanosilver gel ethanol extracts of katuk leaf, then gradually added triethanolamine, added phenoxyethanol, propylene glycol and then stirred.

\section{Antibacterial activity test}

The antibacterial activity test of Nanosilver gel preparations was carried out using the Well method. Each 1 $\mathrm{ml}$ of liquid medium was introduced into $1 \mathrm{ml}$ of bacterial inoculum (BHIA medium for $P$. acne and TSB medium for S. aureus) (Table 2). 
Table 2. Test results for the antibacterial activity of nanosilver gel.

\begin{tabular}{|c|c|c|c|c|c|c|c|c|}
\hline \multirow[t]{3}{*}{ FORMULA } & \multicolumn{4}{|c|}{ BACTERIA P. acne } & \multicolumn{3}{|c|}{ BACTERIA S.aureus } & \multirow{3}{*}{ category } \\
\hline & \multicolumn{2}{|c|}{$\begin{array}{c}\text { Inhibitory } \\
\text { zone diameter } \\
(\mathrm{mm})\end{array}$} & \multirow[t]{2}{*}{ average } & \multirow[t]{2}{*}{ category } & \multicolumn{2}{|c|}{$\begin{array}{l}\text { Inhibitory } \\
\text { zone } \\
\text { diameter } \\
(\mathrm{mm})\end{array}$} & \multirow[t]{2}{*}{ average } & \\
\hline & 1 & 2 & & & 1 & 2 & & \\
\hline 1 & 26 & 26 & 26 & Very strong & 12 & 12 & 12 & Strong \\
\hline 2 & 27 & 27 & 27 & Very strong & 12 & 12 & 12 & Strong \\
\hline 3 & 28 & 28 & 28 & Very strong & 12 & 12 & 12 & Strong \\
\hline $\mathbf{K}+$ & 40 & 40 & 40 & Very strong & 30 & 30 & 30 & Very strong \\
\hline K- & 0 & 0 & 0 & - & 0 & 0 & 0 & - \\
\hline
\end{tabular}

*Note:

Source: Own Study

Fl

$F 2$

F3

Control +

Control -

It was then poured up to $20 \mathrm{ml}$ into a sterile petri dish and allowed to condense. After condensing, holes were made in the medium by inserting a sterile block, after which each hole was up to $50 \mathrm{mg}$ for each sample, positive control using $1 \%$ clindamycin gel, while negative control using a base, each petri dish was then at $37^{\circ} \mathrm{C}$ incubated for 24 hours under anaerobic conditions for $P$. acnes in the anaerobic vessel, while aerobic conditions for $S$. aureus.

\section{Gel evaluation}

Organoleptic, visual observation of the smell, shape and color of the resulting Nanosilver gel.

Viscosity test, Nanosilver gel was added to the beaker until it reached $10 \mathrm{ml}$, then the L-4 spindle was added to the gel preparation up to the specified limit. The measurements were carried out with a viscometer at a speed of $50 \mathrm{rpm}$ for 1 minute.

pH measurement, $\mathrm{pH}$ measurement is carried out with a calibrated $\mathrm{pH}$ meter and the inspection is carried out every 2 weeks for 8 weeks (expected $\mathrm{pH}$ range between 4.5 and 6.5). Scattering test, which is carried out to ensure an even distribution of the gel when applied to the skin. The Nanosilver gel was weighed up to $0.5 \mathrm{~g}$ and then placed in the middle of a large round glass. Another round glass or other transparent material and a weight of $150 \mathrm{~g}$ is placed on the gel, left for 1 minute, then the distribution diameter is recorded. Good gel distribution between 5-7 cm (10).
Physical stability tests were carried out at various storage temperatures, namely at low temperature $\left(5^{\circ} \mathrm{C} \pm 2{ }^{\circ} \mathrm{C}\right)$, high temperature $\left(40^{\circ} \mathrm{C} \pm 2{ }^{\circ} \mathrm{C}\right)$ and room temperature $\left(25^{\circ} \mathrm{C}\right.$ $\pm 2^{\circ} \mathrm{C}$ ). The purpose of the physical stability test is to determine whether the gel preparation that is stored for 2 months at different temperatures changes physically. The observations made include organoleptic, homogeneity, $\mathrm{pH}$, dispersibility and viscosity. The stability test of the gel preparation is taken from the best formula.

\section{Results}

The results of MIC optimization of katuk leaf ethanol extract obtained at a concentration of $0.08 \%$ in $P$. acnes bacteria and $0.16 \%$ in $S$. aureus bacteria. After the MIC value of the katuk leaf ethanol extract nanosilver has been obtained, the variation of the Katuk leaf ethanol extract concentration for the synthesis of the Nanosilver is multiplied by $1 \mathrm{x}, 2 \mathrm{x}$ and $3 \mathrm{x}$ the minimum inhibitory concentration of $0.16 \% ; 0.32 \%$ and $0.48 \%$ continued for the nanoparticle characterization test.

Analysis using PSA shows the diameter value of Nanosilver 1 particles has a size of $164.40 \mathrm{~nm}$, while Nanosilver 2 has a size of $176.47 \mathrm{~nm}$. While Nanosilver 3 has a particle size of 194.95. The higher the concentration of Katuk leaf extract in nanosilver synthesis, the larger the nanoparticles produced. It can be concluded from the results of the analysis with PSA that Nanosilver 1 has the smallest particle size in comparison to Nanosilver solutions 2 and 3. 
The analysis using FTIR is said to find that there is a bond between the active ingredients present in the ethanol extract of katuk leaf with silver nitrate to produce nanosilver.
Based on (Figure 1), the peak shows the wavenumber 3253.10 , which is an $\mathrm{O}-\mathrm{H}$ group with compounds of the phenol and alcohol type (Skoog. 1998).

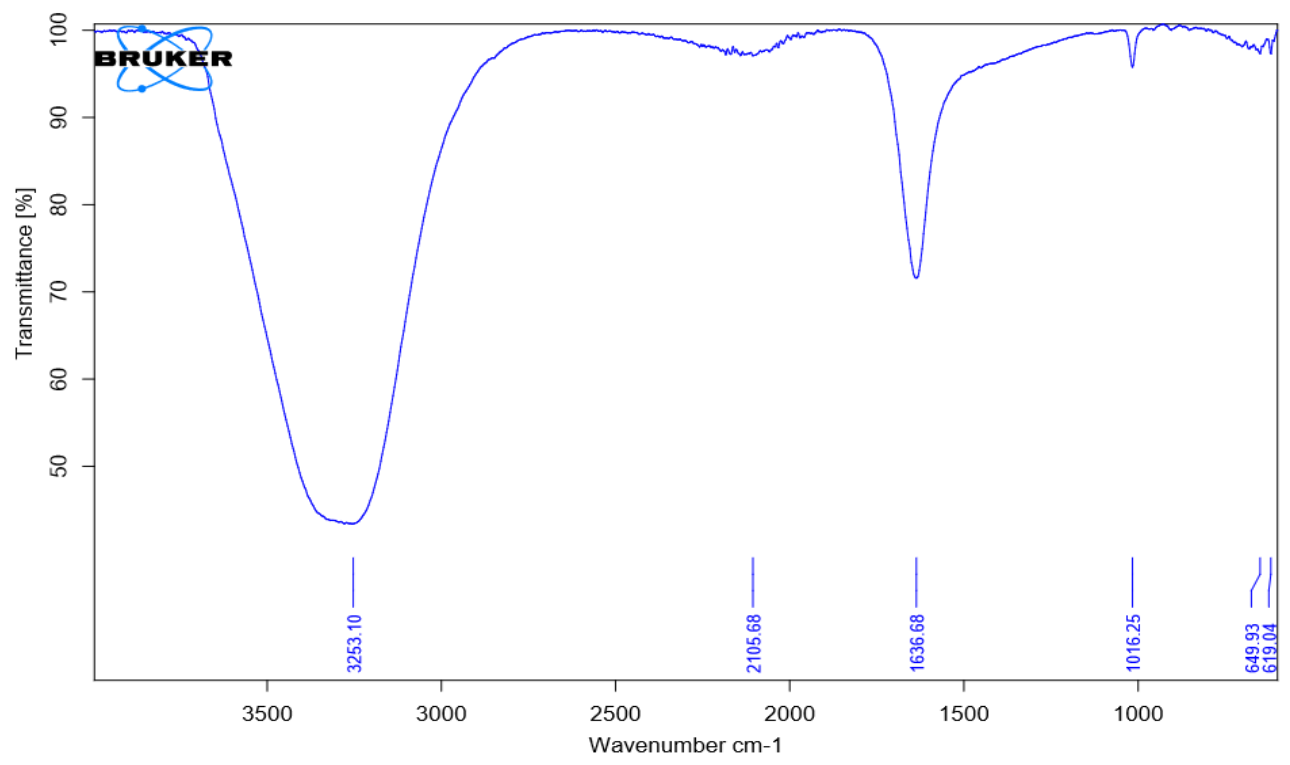

Source: Own Study

Figure 1. Results of nanosilver spectra of katuk leaf ethanol extract by FTIR.

The presence of $\mathrm{O}-\mathrm{H}$ groups derived from katuk leaf ethanol extract is required to accelerate the reduction process of ag + ions. There is also a peak at wave number 2105.68 is a $\mathrm{C} \equiv \mathrm{C}$ bond with an alkaline compound type, there is also a peak at wave number 1636.68 is a $\mathrm{C}=\mathrm{C}$ bond with an alkene compound type, with other peaks it is also in the wave range 101625 is a CO bond with a kind of alcohol compound, ether, carboxylic acid and ester, and at numbers 649.93 and
619.04 is a $\mathrm{CH}$ bond with a kind of alkene compound with strong intensity.

Results of the test properties of silver nanoparticles and the test of antibacterial activity, the best formula is Formula 1, namely Nanosilvergel, which synthesizes with a concentration fluctuation of $0.16 \%$ Katuk leaf ethanol extract with $10 \mathrm{mM}$ silver nitrate solution (1: 9) becomes. This optimal formula is used for stability and stimulus tests. Figure 2 show results on katoper leaf ethanol extract.

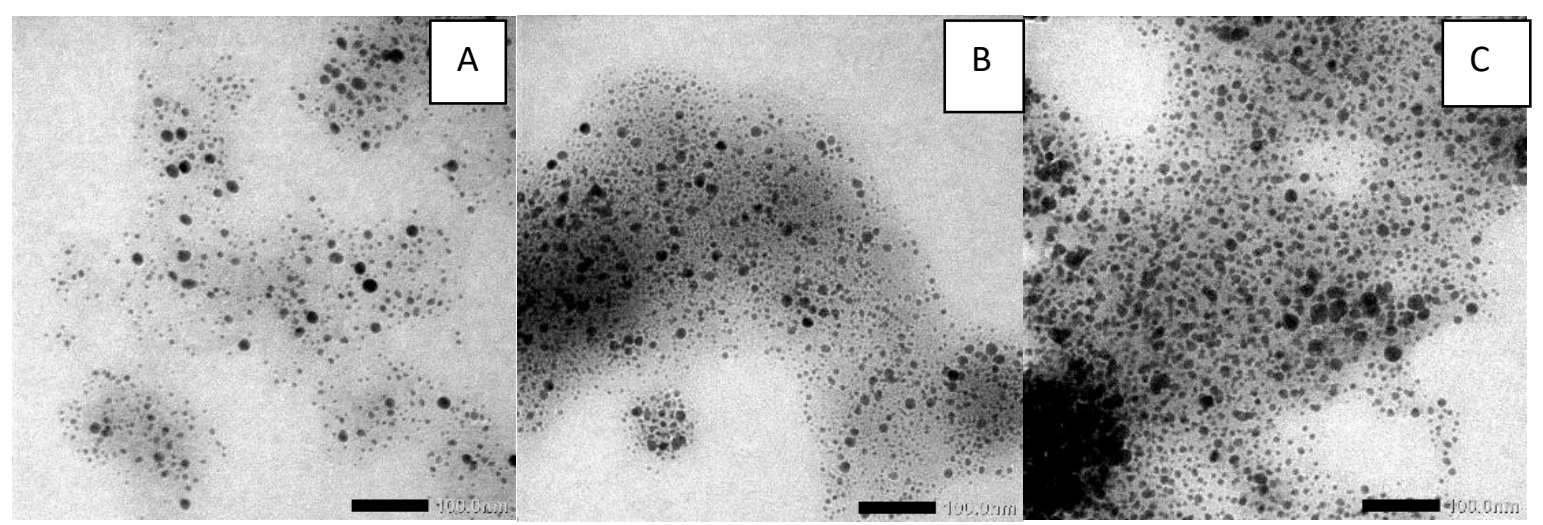

Note: A. Nanosilver 1: $0.16 \%$ katuk leaf ethanol extract concentration with $10 \mathrm{mM}$ silver nitrate (1:9). B.: Nanosilver 2: concentration of ethanol extract of katuk leaf 0.32\% with $10 \mathrm{mM}$ silver nitrate (1: 9). C. Nanosilver 3: 0.48\% katuk leaf ethanol extract concentration with $10 \mathrm{mM}$ silver nitrate (1: :9).

Figure 2: TEM results on katoper leaf ethanol extract of $100 \mathrm{~nm}$ magnification. 
The Nanosilver Gel Organoleptic Test was performed by visually observing the shape, color and smell of the gel. Organoleptic results for Nanosilver gel preparations with three different storage temperatures from
Table 3 show that there is a significant change in color at 400 ${ }^{\circ} \mathrm{C}$. This is likely due to temperature and storage factors that can affect the form of the preparation.

Table 3: Results of observations of organoleptic stability test for nanosilver gel.

\begin{tabular}{|c|c|c|c|c|}
\hline Temperature $\left({ }^{\circ} \mathrm{C}\right)$ & Storage time & & Organoleptic & \\
\hline & (week) & color & Smell & Shape \\
\hline \multirow[t]{4}{*}{5} & 2 & Golden yellow & Distinctive & semisolid \\
\hline & 4 & golden yellow & Distinctive & semisolid \\
\hline & 6 & Golden yellow & Distinctive & semisolid \\
\hline & 8 & golden yellow & Distinctive & semisolid \\
\hline \multirow[t]{4}{*}{$25-30$} & 2 & golden yellow & Distinctive & semisolid \\
\hline & 4 & golden yellow & Distinctive & semisolid \\
\hline & 6 & Brown & Distinctive & semisolid \\
\hline & 8 & Brown & Distinctive & semisolid \\
\hline \multirow[t]{4}{*}{40} & 2 & ash & Distinctive & semisolid \\
\hline & 4 & ash & Distinctive & semisolid \\
\hline & 6 & ash & Distinctive & semisolid \\
\hline & 8 & ash & Distinctive & semisolid \\
\hline
\end{tabular}

Statistical data using the two-way ANOVA method gave a significant value of $0.047<0.05$, which means that there is a significant difference in viscosity value caused by a difference in storage temperature, and Anova received a significant one Value of $0.114>0.05$, which means that there is no significant difference in the value of viscosity caused by the storage time of nanosilver gel.

The results of the $\mathrm{pH}$ stability test showed a decrease in $\mathrm{pH}$ at a storage temperature of $40^{\circ} \mathrm{C}$. This can be caused by various factors such as temperature, storage containers and active substances that are oxidized during storage. However, the decrease in the $\mathrm{pH}$ of the Nanosilver gel is still in the normal $\mathrm{pH}$ range of the skin, which is between 4.5 and 6.5. From this it can be concluded that the Nanosilver gel meets the $\mathrm{pH}$ requirements of the skin. A significant value of $0.007<0.05$ is obtained from the statistical data using the two-way ANOVA method, which means that there is a significant difference in $\mathrm{pH}$ due to differences in storage temperature and a significant value of
$0.147>0,05$, which means that there is no significant difference due to the long storage time of the nanosilver gel.

Statistical data using the two-way ANOVA method gave a significant value of $0.390>0.05$ at the storage temperature and a significant value of $0.114>0.05$, which means that there was no significant difference in the distributability between the temperature and the Storage time. It can be concluded from this that the Nanosilver gel has a good dispersion value between 5.5 and $6.1 \mathrm{~cm}$ (11).

\section{Discussion}

The polydispersity index value indicates the uniformity of the particle size. The smaller the polydispersity index value, the more homogeneous the particle size, the polydispersity index value $>0.5$ indicates a high degree of heterogeneity, and vice versa, if it approaches 0 , it indicates a uniform particle size (12).

The polydispersity in Nanosilver solutions 1, 2 and 3 has a polydispersity index value $<0.5$. This shows that the nanoparticle size of all samples is still uniform. In addition to the particle size, the zeta potential is an important feature 
of nanoparticles in order to predict the stability of colloid solutions. The interaction between particles is important for the stability of colloidal solutions.

The zeta potential is a value that indicates the repulsive force between particles. Zeta potential nanoparticles are commonly used to characterize the surface charge properties of zeta nanoparticles, which may reflect the electrical potential of a particle, and are affected by the composition of the particles and the media in which they are dispersed.

It was shown that nanoparticles with a potential above (+/-) $30 \mathrm{mV}$ are stable in suspension because the surface charge prevents the aggregation of particles (13). The zeta potential analysis shows relevant results and confirms the distribution pattern data and the polydispersity index.

According to Mardliyati et al. (2012) indicate nanoparticles with a very small size and low polydispersity index have a high zeta potential value (above $30 \mathrm{mV}$ ), which means that they are quite stable. While particles of large size and polydispersity index are high, the zeta potential value shown is also low.

The results of the zeta potential (Table 4) show that Nanosilver 1 has a zeta potential of -33 , Nanosilver 2 has a zeta potential of -8.7 and Nanosilver 2 has a zeta potential of -10.4. From this it can be concluded that the Nanosilver 1 solution is a stable colloidal solution.

Table 4. Results of PSA and zeta analysis potential.

\begin{tabular}{rcccc}
\hline no & sample & $\begin{array}{c}\text { Particle } \\
\text { diameter }(\mathbf{n m})\end{array}$ & Polydispersity Index & Zeta Potential $(\mathbf{m V})$ \\
\hline $\mathbf{1}$ & Nanosilver 1 & 164,40 & 0,073 & $-33,1$ \\
\hline $\mathbf{2}$ & Nanosilver 2 & 176,47 & 0,075 & $-8,7$ \\
\hline $\mathbf{3}$ & Nanosilver 3 & 194,95 & 0,086 & $-10,4$
\end{tabular}

*Note:

Nanosilver 1: $0.16 \%$ katuk leaf ethanol extract concentration with $10 \mathrm{mM}$ silver nitrate (1: 9)

Nanosilver 2: $0.32 \%$ katuk leaf ethanol extract concentration with $10 \mathrm{mM}$ silver nitrate (1: 9)

Nanosilver 3: 0.48\% katuk leaf ethanol extract concentration with $10 \mathrm{mM}$ silver nitrate (1: 9)

Nanosilver 1 shows that there are fewer deposits compared to samples compared to Nanosilver solutions 2 and 3 .

The higher the concentration ratio of katuk leaf ethanol extract in the formulation of Nanosilver, the more clearly the amount of deposits is seen in the synthesized solution(2). This is because nanosilver synthesized from plant extracts has poor stability, so the lack of agitation at the time of nanosilver synthesis allows for easy aggregation of nanosilvers.

The reaction should be accelerated by stirring and the solution should be homogenized. So that the process can prevent aggregation. The tendency of nanoparticles to aggregate is caused by Brownian motion effects and Van der Waals forces in solution. This tendency of nanoparticles to aggregate causes the size / diameter of nanoparticles to be uneven.

The aggregation of the nanoparticles can be observed from the results of the PSA analysis, in which the size of the nanoparticles varies between $164.40 \mathrm{~nm}$ and $194.95 \mathrm{~nm}$. Nanoparticle aggregation can be described as a two-stage process. In the first step, particles come closer and collide with each other (transport step). The second step are particles that collide with each other (binding step). In order to prevent nanopaticles from sticking together and settling in solution, nanoparticles must be stabilized (14).

The inhibition of Nanosilver gel against $P$. acnes bacteria in Formula 1 is $26 \mathrm{~mm}$, Formula 2 is $27 \mathrm{~mm}$ and Formula 3 is $28 \mathrm{~mm}$, so that it is classified as very strong, while the inhibition of Nanosilver -Gel against $S$. aureus bacteria is good in formulas 1,2 and 3 they have an inhibition zone of $12 \mathrm{~mm}$, which is included in the strong category. The 2 -way Anova test results show a Sig value of $0.63<0.05$, which means that there is no influence between any formula if the concentration of Nanosilver varies on the inhibition of bacteria. However, the value of the inhibition diameter of Propionibacterium acnes bacteria for the effect of increasing variations in the concentration of nanoparticles tends to increase, but not significantly.

The strain or type of bacteria is also an important determinant for explaining the ability of Nanosilver gels to be antibacterial, since they have their own complex organelle arrangement for each bacterium, which has different effects when interacting with silver nanoparticles.

\section{Conclusion}

The green synthesis of Nanosilver using ethanol extract from Katuk leaf as a reducing agent was successfully carried out. The variation in the concentration of the katuk leaf ethanol extract influences the size of the particles 
formed. The antibacterial activity of the nanosilver gel has an antibacterial cause for acne with a very strong category.

The strain or type of bacteria is also an important determinant for explaining the ability of Nanosilver gels to be antibacterial, since they have their own complex organelle arrangement for each bacterium, which has different effects when interacting with silver nanoparticles.

Formulation and evaluation of the nanosilver gel using bioreductor ethanol extract of Katuk leaf (Sauropus androgynus ( $l$ ) Merr) as antibacterial Nurfadilah, Yunahara Farida, Faizatun

Introduction: The current type of nanoparticle that attracts a lot of attention in the pharmaceutical field is Nanosilver. Nanosilver can be acted as an antimicrobial. The aim of this study is to obtain the Nanosilver gel preparation from katuk leaf extract, which is effective as an antibacterial agent against acne. Materials and Methods: Katuk leaf extract remains as a reducing agent in the synthesis of Nanosilver using a green synthesis method. Nanosilver characterization was performed using PSA, FTIR and TEM. Results and Discussions: Particle size of Nanosilver (Katuk leaf extract concentration $0.16 \%$ with a silver nitrate volume of $10 \mathrm{mM}$ is 1: 9) of $164.40 \mathrm{~nm}$, Nanosilver (Katuk leaf extract Concentration $0.32 \%$ with silver nitrate volume $10 \mathrm{mM}$ is 1: 9) of $176.47 \mathrm{~nm}$ and Nanosilver (0.48\% katuk leaf extract concentration with a volume of $10 \mathrm{~mm}$ silver nitrate of 1: 9) of $194.95 \mathrm{~nm}$. Antibacterial activity using the Well method was shown that the nanosilver gel from Katuk leaf extract had an inhibitory effect on $P$. acnes bacteria with an inhibition zone of $26 \mathrm{~mm}$ classified as very strong, and 12 $\mathrm{mm}$ was strongly categorized against $S$. aureus bacteria, namely in Formula 1. Conclusion: A variation in the concentration of katuk leaf extract influences the size of the particles formed. The Nanosilver of katuk leaf extract has an antibacterial cause for acne with a very strong category. Keywords: Acne; Nanosilver gel; Antibacterial; Katuk leaf.

\section{References}

1. Meilina NE, Hasanah NA. Aktivitas Antibakteri Ekstrak Kulit Manggis (Garcinia mangostana L.) Terhadap Bakteri Penyebab Jerawat. J Farmaka. 2018;10:322-8. 2. Nalawati AN. Sintesis nanopartikel perak (NPAg) dengan metode yang ramah lingkungan dan kajian aktifitasnya dalam menghambat pertumbuhan bakteri gram positif dan bakteri gram negatif. Institut Pertanian Bogor; 2015.

3. Fabiani VA, Sutanti F, Silvia D, Putri MA. Green Synthesis Nanopartikel Perak Menggunakan Ekstrak Daun Pucuk IDAT (Cratoxylum glaucum) sebagai Bioreduktor. Indones J Pure Appl Chem. 2018;1(2):68.

4. Mukhriani, Tahar N, Astha ASW. Uji Aktivitas Antibakteri Hasil Fraksinasi Dari Ekstrak Metanol Daun Katuk (Sauropus androgynus) Terhadap Beberapa Bakteri Patogen. Jf Fik Uinam. 2014;
5. Lestari ND. Pengaruh variasi konsentrasi larutan nanopartikel perak sebagai bahan aditif dalam batako terhadap porositas dan kuat tekan batako. Universitas Negeri Yogyakarta; 2016.

6. Huys G. Antibiotic susceptibility testing of aquaculture-associated bacteria with the broth macrodilution method (mic determination). Lab Microbiol KL Ledegankstr35 B-9000 Gent. 2002;3-11.

7. Balachandran YL, Girija S, Selvakumar R, Tongpim S, Gutleb AC, Suriyanarayanan S. Differently Environment Stable Bio-Silver Nanoparticles: Study on Their Optical Enhancing and Antibacterial Properties. PLoS One. 2013;8(10).

8. Bar H, Bhui DK, Sahoo GP, Sarkar P, Pyne S, Misra A. Green synthesis of silver nanoparticles using seed extract of Jatropha curcas. Colloids Surfaces A Physicochem Eng Asp. 2009;348(1-3):212-6.

9. Niazi SK. Handbook of pharmaceutical manufacturing formulations: Semisolid products (volume 4 of 6).

Handbook of Pharmaceutical Manufacturing Formulations: Semisolid Products (Volume 4 of 6). 2004.

10. Sayuti NA. Formulasi dan Uji Stabilitas Fisik Sediaan Gel Ekstrak Daun Ketepeng Cina (Cassia alata L.). J

Kefarmasian Indones. 2015;5(2):74-82.

11. Garg A, Aggarwal D, Garg S, Singla AK. Spreading of semisolid formulations: An update. Pharmaceutical Technology North America. 2002.

12. Ningsih N, Yasni S, Yuliani S. Sintesis Nanopartikel Ekstrak Kulit Manggis Merah dan Kajian Sifat Fungsional Produk Enkapsulasinya. J Teknol dan Ind Pangan.

2017;28(1):27-35.

13. Pertiwi D, Djajadisastra J, Mutalib A, Pujiyanto A. Pembuatan, Karakterisasi dan Uji In Vitro Nanopartikel Emas Berbasis Konjugat Gom Arab-Vinkristin. J Ilmu Kefarmasian Indones. 2018;16(1):6-11.

14. Masakke Y, Sulfikar, Rasyid M. Biosintesis Partikelnano Perak Menggunakan Ekstrak Metanol Daun Manggis ( Garcinia mangostana L . ). J Sainsmat. 2015;4(1):28-41. 